\title{
'n Nuwe antwoord op 'n ou probleem: Die kritiese realisme van Wentzel van Huyssteen
}

\author{
GC Velthuysen
}

\begin{abstract}
A new answer to an old question: The critical realism of Wentzel van Huyssteen

In this article a critical investigation is made into the theological model of Professor Wentzel van Huyssteen. His model is placed in the context of the age-old issue of theological rationality and the question whether or not theology is science or as such has a scientific character. His utilisation of latterday philosophical insights into the nature of science in an attempt to arrive at a positive answer, is treated positively - as is his concept and model as such. The gist of his argument is conceded. Conclusions with special relevance to the South African theological situation are drawn while some critical remarks, indicative of the fact that this concept should also only be valued as provisional and not final, are made.
\end{abstract}

\section{DIE PROBLEEM}

Die vraag na die wetenskaplikheid al dan nie van die teologie as sodanig en van die sistematiese teologie of dogmatiek in die besonder, was van vroeg reeds op die teologiese agenda. 'n Positiewe antwoord op hierdie vraag was ook nog altyd die ideaal van elke teoloog/dogmatikus wat hom daarmee besig gehou het. Die rede hiervoor is voor-diehand-liggend; met hierdie vraag kom die sin, betekenis en waarde van die teologiese arbeid onder skoot, sodat die antwoord daarop vir die teoloog van eksistensiële betekenis word.

Die vraag kom op daardie oomblik na vore wanneer die teoloog in gesprek tree met wetenskaplikes uit ánder dissiplines en hy dit beleef dat die wetenskaplikheid van sy arbeid bevraagteken word. Dit het dadelik tot gevolg dat sy deelname aan die gesprek onder 'n vraagteken geplaas word. Dit is tog immers ondenkbaar dat daar, binne die breëre akademiese debat, ruimte gegee sal word aan argumente wat ten beste as kwasi-wetenskaplik en ten slegste as fantasie beskou kan word. Dit 
het verder ook nog ernstige implikasies vir die posisie van die teologie, en weer eens in die besonder die sistematiese teologie, aan 'n universitêre fakulteit.

Reeds Thomas Aquinas het dit nodig gevind om hierdie problematiek ter hand te neem en vir hom was die probleem nié so akuut soos vir 'n hedendaagse teoloog nie. Toe hy sy Summa Theologica geskryf het, was die bestaan van God nog nie 'n probleem nie. Dit was algemeen en as vanselfsprekend aanvaar. Trouens, die algemeen aanvaarde opvatting van die dag was dat daar vanuit die synde tot werklike kennis aangaande God gekom kan word. Dit was moontlik omdat aanvaar is dat God nie tot ' $n$ ánder synswerklikheid behoort as die een wat vir die menslike sintuie en rede toeganklik is nie. Inteendeel, $\mathrm{Hy}$ is gesien as die bopunt van die piramide van die syn, met die implikasie dat dit wat op die basislyn van die piramide plaasvind en die kennis wat op grond daarvan verwerf word, bydra tot kennis van Hom wat die spits vorm. Die moderne insig, dat die teologie hom besig hou met ' $n$ onsigbare werklikheid wat nêrens en op geen manier waarneembaar en kontroleerbaar is nie, sou destyds vreemd voorgedoen het.

Nogtans vind Aquinas dit nodig om die status van die teologie as wetenskap te verdedig. Dit het immers tóé alreeds duidelik geword dat, as die teologie dan ' $n$ wetenskap is, hy dit op ' $n$ ander wyse is as byvoorbeeld die wiskunde. Daarom sien Aquinas se argument soos volg daaruit.

Daar is twee soorte wetenskap. Die een soort werk met grondbeginsels en uitgangspunte wat direk vir die rede toeganklik is, soos byvoorbeeld die wiskunde. Dan is daar die ánder soort, wat met grondbeginsels en uitgangspunte werk wat deur die lig van 'n ander, basiswetenskap, verstaanbaar en deursigtig word. As voorbeeld van so 'n wetenskap noem hy die musiek (kontrapunt) wat werk met grondbeginsels wat deur die wiskunde toeganklik word. Op dieselfde wyse is die teologie wetenskap, want dit gaan uit van grondbeginsels wat in die lig van 'n ander wetenskap deursigtig word, naamlik die kennis van God en die saliges! Die musiek glo (aanvaar) die grondbeginsels wat deur die wiskunde aan hom gebied word en só glo (aanvaar) die teologie die grondbeginsels wat deur God geopenbaar is.

As Aquinas dit nodig gevind het om 'n lansie vir die teologie te breek, het diè noodsaak in die moderne tyd oneindig dringender geword. Die geloof in die bestaan van God is nie meer 'n vanselfsprekendheid nie. Inteendeel, die moderne, Europees-beïnvloede lewensen wêreldbeskouing het vir God nie plek nie en is, as gevolg van 
verskillende faktore waaronder die invloed van die denke van Feuerbach, Marx, Nietzsche en Freud (Küng 1978) uitgesproke ateïsties. Om à lá Aquinas vandag te probeer om die wetenskaplikheid van die teologie te rugsteun met 'n beroep op die openbaring van God, sou gevolglik sinloos en futiel wees.

Dit is egter ook duidelik dat, selfs waar die bestaan van God nie 'n probleem is nie en in die geloof aanvaar word, die ontologiese struktuur wat in die Middeleeue gegeld het, nie nou meer ' $n$ uitkoms bied nie. Minstens sedert die Verligting is dit duidelik dat daar nie op rasionele wyse vanuit die empiriese werklikheid tot die bestaan en Persoon van God gekonkludeer kan word nie. Daarom staan die teologie wawyd oop vir die aanklag dat nie een van sy uitsprake ooit gekontroleer kan word nie en dat alles by hom dus aan die willekeur prysgegee is. Binne die huidige debatsklimaat help dit hom ook nie om in so ' $n$ geval hom op die uitsprake van die Bybel te beroep nie. Dán kom die beswaar onmiddellik na vore dat die Bybel(-skrywers) sélf willekeurige uitsprake maak wat ewe min kontroleerbaar is (Ott 1981: 88).

Dit moet in gedagte gehou word dat as gevolg van enersyds die verstommende prestasies van die natuurwetenskappe en andersyds die wetenskapsfilosofiese insette van veral die sogenaamde Wiener Kreis met sy logies-positiwisme, daar 'n populêre eenheidsbeeld van die verskynsel 'wetenskap' ontstaan het, wat nie veel ruimte daarvoor laat dat 'n verskynsel soos die teologie as ' $n$ wetenskap gekarakteriseer kan word nie. As belangrikste kenmerk van hierdie eenheidsbeeld moet juis hierdie eis tot kontroleerbaarheid of verifikasie aangedui word. Al geld hierdie beskouing binne wetenskapsfilosofiese kringe grotendeels as agtergehaald en verouderd, geld dit in die praktyk nog onverminderd as die basiese eis vir wetenskaplikheid en is dit waarskynlik nog steeds die grootste bron van verleentheid vir die teoloog wat hom met betrekking tot sy wetenskaplikheid wil verantwoord. Soos later sal blyk is een van die standaardargumente waarmee die wetenskaplikheid van die teologie verdedig word, niks anders nie as 'n uitdrukking van hierdie verleentheid en 'n eensydige reaksie waardeur die teologie in dieselfde positiwistiese hoek teregkom.

\section{ANTWOORDE}

Die antwoord van Aquinas is reeds gegee en hoef nie nou weer ter sprake gebring te word nie. Dit is in ieder geval ook nie meer werklik 
ter sake nie aangesien die vooronderstellings waarkragtens dit geformuleer is, nie meer geld nie. Dit sal sinvol wees om baie kortliks aandag aan 'n paar twintigste-eeuse antwoorde te gee. Dan is ons meteen midde in die huidige debat.

Karl Barth veranker die wetenskaplikheid van die teologie in sy eiesoortigheid. Hy wil dit naamlik waardeer sien as 'n kritiese werksaamheid van die kerk en beskryf dit as 'n maatreël wat die kerk tref ten aansien van die aanvegbaarheid en verantwoordelikheid van sy spreke (Barth 1947: 2). Dit is egter nie voldoende motivering om die teologie as wetenskap aan te dui nie en daarom lê hy ook klem op die volgende: Soos alle ander wetenskappe is die teologie ook menslike besig-wees (Bemühung) met 'n bepaalde kennisobjek. Soos alle ander wetenskappe volg dit ' $n$ bepaalde kennisweg en is dit daartoe in staat om oor hierdie kennisweg rekenskap te gee (Barth 1946: 6).

Hieruit volg dit dan vir Barth dat die wetenskaplikheid van die teologie afhang van die mate waarin hy hom met sy opdrag besig hou. Wanneer hy, by sy opdrag verby, homself gaan bemoei met dese en gener problematiek op dese en gener vlak van die werklikheid, sal hy inderdaad sy karakter as wetenskap verbeur. Wat die opdrag betref, dié is duidelik en op die man af; kritiek op en regstelling aan die kerklike verkondiging in ooreenstemming met en na aanleiding van die openbaring soos in die Heilige Skrif betuig.

Ook Paul Tillich laat val die klem op die teologie se eiesoortigheid, maar hy begrond dit anders as Barth. Dit lê nie vir hom in die opdrag aan die teologie nie, maar in die kennishouding van die teologie ten aansien van sy 'objek'. Kenmerkend van wetenskaplikheid oor die algemeen is naamlik dat die wetenskap(like) op 'n afstand van sy objek gaan staan om homself sodoende die kritiese afstand te gun sodat die ideaal van objektiwiteit bereik kan word. In kontras hiermee word die teologie as 't ware opgeneem deur die objek waarmee hy besig is. Distansiëring van die objek sou neerkom op 'n verloëning daarvan. Die houding van die teoloog ten aansien van sy objek is idealiter een wat gekenmerk word deur hartstog, vrees en liefde - dus uit en uit 'n eksistensiële verhouding (Tillich 1968: 26).

Uit hierdie unieke verhouding spruit die unieke metode waarvan die teologie hom bedien. Volgens Tillich maak die sistematiese teologie gebruik van die metode van korrelasie. Deur hierdie metode word die inhoud van die Christelike geloof verklaar deur eksistensiële vrae en teologiese antwoorde met mekaar te korreleer. Dit kan soos volg geformuleer word: God antwoord op die vrae van die mense en, onder 
die indruk van God se antwoorde, stel die mens sy vrae. Die werkwyse van hierdie metode is die volgende: dit gee ' $n$ analise van die menslike situasie waaruit die eksistensiële vrae na vore kom en toon aan dat die simbole van die Christelike boodskap (evangelie) die antwoorde op hierdie vrae is (Tillich 1968: 67-76).

Henrikus Berkhof het ' $n$ interessante en unieke antwoord op die probleem. Dit is vir hom vanselfsprekend dat die teologie wetenskaplik is, want dit werk op presies dieselfde manier as enige ander intellektuele bedryf wat homself as wetenskap beskou. Om wetenskaplik besig te wees, is om uit te gaan 'van een tevoren gegeven werkelijkheid die het wil doorgronden en verhelderen met behulp van begrippen die door onderscheiding en verbinding in de gegeven stof geleding, samenhang en doorzicht aanbrengen' (Berkhof 1973: 37). Dit is vir hom egter nie so vanselfsprekend dat die teologie homself wetenskap moet noem nie. Hy meen egter tog dat dit nuttig kan wees! Die wetenskap is immers ' $n$ beskeie (!) bedryf omdat mens nooit daarmee klaarkry nie en deur dit te besef, kan die geloofsleer (Berkhof gee voorkeur aan hierdie term bo dogmatiek en sistematiese teologie) verhinder word om die absoluutheid wat eie is aan sy objek, ook vir homself toe te eien.

Hy lê egter ook, nadat hy die ooreenkoms tussen die teologie en die ander wetenskappe op die spits gedryf het, klem op die radikale verskil wat daar bestaan. Die wetenskap as sodanig het algemeenheid as kenmerk (wanneer die natuurwetenskap as model geneem word en die werk van Windelband en Rickert ten opsigte van die geesteswetenskappe buite rekening gelaat word), maar die teologie berus op 'n oortuiging wat hierdie algemeenheid mis en waarvan gesê word dat dit net as die vrug van 'n besondere werking van die Heilige Gees tot stand kom. Dit diskwalifiseer egter (aldus Berkhof) nie die teologie as wetenskap nie. Dit bring eerder die vraag na die grens van wetenskaplikheid as sodanig na vore en vestig die aandag op die feit dat dit van alle wetenskappe waar is dat, hoe dieper en omvattender daar na die waarheid gesoek word, hoe sterker word die subjektiewe element en des te geringer die algemene insigtelikheid en verifieerbaarheid. Sy konklusie is belangrik.

Wie dit bezinningsveld daarom buiten de wetenschap houdt, veroordeelt de wetenschap ertoe, zich tot de oppervlakte - fenomenen te beperken en elk vragen naar laaste vooronderstellingen, samenhangen en uitzichten te negeren, wat tot de conclusie moet leiden: Wat wij kunnen weten is nie echt belangrijk; en het belangrijke kunnen wij niet weten. Zo gezien is de vraag of 
geloofsleer wetenschap moet heten, van beslissende betekenis voor de wetenschap zelf en haar reikwijdte en doelstellingen (Berkhof 1973: 37).

Wanneer Heinrich Ott (1981: 92) sý antwoord op die probleem formuleer, is dit duidelik dat hy in gesprek met die logies-positivisme verkeer. Hy wys daarop dat daar ook ánder wetenskappe is wat nie aan die eis tot verifikasie kan voldoen nie, soos byvoorbeeld die filosofie. Maar al is so ' $n$ wetenskap nie 'positief' in die sin wat byvoorbeeld die fisika dit is nie, werk hy ook met 'n baie duidelike metodiese en wetenskaplike dissipline. Vir hierdie wetenskappe gaan dit nie om die bereiking van wetenskaplik (in positiwistiese sin)-'regte' resultate nie, maar oor die algemeen eerder om uitleg en verklaring; om die verstaanbaarmaking van sinsamehange. Die teologie is, vir sover as wat dit sy metode betref, aan hierdie wetenskappe verwant. Vandaar sy karakterisering van die teologie as 'n 'hermeneutiese' wetenskap.

\section{VERDERE PROBLEME VANUIT DIE ANTWOORDE}

Dit is duidelik dat bostaande keuse van behandelde dogmatici baie willekeurig en subjektief van aard is en boonop maar' $n$ klein dwarssnit uit die dogmatiese spektrum verteenwoordig. Die beperkende omvang van ' $n$ artikel van hierdie aard is in die eerste plek daarvoor verantwoordelik, maar daarnaas moet gemeld word dat, al sou die voorbeelde ad nauseam vermeerder word, daar nie veel ander geluide gehoor sou word nie. Daar is hoogstens verskille wat betref die invalshoek en die aksente wat gelê word, maar die basiese argument is die bekende: die teologie is uniek as gevolg van die uniekheid van sy objek - dit is wetenskap, maar binne die raamwerk van die wetenskappe as sodanig is dit 'n Fremdkörper of, anders gesê, vind dit homself in 'n stormvrye gebied wat dit grotendeels aan die kritiek van die ander wetenskappe onttrek.

Van hieruit kom daar ánder, moeilike vrae na vore - vrae wat inhoudelik nie juis na normale teologiese vrae lyk nie, maar waarby die ernstige dogmatikus nie kan verbygaan nie - in ieder geval nie wanneer die akademiese status van sy wetenskap vir hom belangrik is nie. Dit is vrae soos onder andere die volgende:

- Is dit onvermydelik dat die teologie 'n wetenskap in isolasie sal wees? 
- Moet die teologie daarmee genoeë neem dat hy 'n esoteriese werksaamheid bly, sonder gespreksmoontlikheid buite die enge kring?

- Laat die subjektiewe geloofsverbintenis, dit wat die grondslag van die teologiese werksaamheid is, nog objektiewe wetenskapsbeoefening toe?

- Is dit vir 'n teoloog nog moontlik om, vanuit 'n persoonlike geloofsverbintenis, asook vanuit ' $n$ identifisering met ' $n$ spesifieke teologiese tradisie, uitsprake te maak op 'n wyse waarop die teologie intellektuele integriteit kan behou?

Dit is vrae van kenteoretiese aard wat as metateologies beskou kan word en wat eerder op die vlak van die wetenskapsfilosofie tuishoort. Dit lyk egter noodsaaklik dat die teoloog (en verstaan asseblief onder 'teoloog' telkens 'dogmatikus') oor hierdie en soortgelyke vrae duidelikheid sal kry. Die antwoorde hierop is immers van werklike betekenis vir die praktiese beoefening van die dogmatiek as wetenskap.

Dit is die soort vraag waarmee Wentzel van Huyssteen (1986) hom besig hou in sy werk, Teologie as kritiese geloofsverantwoording: Teorievorming in die sistematiese teologie.

\section{VAN HUYSSTEEN SE ANTWOORD: 'N KRITIES-REALISTIESE RASIONALITEITSMODEL}

Hierdie werk van Van Huyssteen is beslis nie 'maklike' leesstof nie. Afgesien van die geweldige komplekse aard van die vraagstelling munt die skrywer nie juis uit wat betref helderheid van formulering nie. Daarby is die terminologie wat deurgaans gebruik word, as gevolg van die vreemdheid daarvan, van so'n aard dat dit nie as maklik toeganklik beskou kan word nie. Maar wie ook al hiermee aan die worstel raak en daarin slaag om die vraagstelling te deurdring en dit sy eie te maak, kom gou agter dat hy te make het met denkarbeid van die hoogste kwaliteit.

\subsection{Sy oogmerk}

Vir' $n$ beoordeling van sy denke is dit in die eerste plek nodig dat daar duidelikheid verkry sal word oor wat hy presies wil bereik en hoe hy dit wil bereik.

Wat miskien moet geld as die basiese vraag wat hy probeer beantwoord, is of dit vir die teologie nog moontlik is om op so 'n wyse 
kontekstueel te spreek dat die bevryding van die evangelieboodskap nog helder en duidelik in al die fasette van die samelewing gehoor sal kan word (Van Huyssteen 1986: 1). Het die teologie dus nog in die Suid-Afrikaanse situasie iets te sê? Die antwoord hierop sal afhang van die antwoord op die volgende vraag: 'Slaag die teoloog werklik daarin om, in die komplekse netwerk van sy uitsprake en argumentasies, iets geloofwaardigs oor God self te sê?' (Van Huyssteen 1986: 1). Met die oog op die program wat hy in hierdie boek volg, formuleer hy hierdie stuk kernproblematiek as dié vraag waarmee hy hom besig hou, op die volgende wyse: 'Wat presies gebeur in die proses van teorievorming waarin ons alledaagse geloofstaal skynbaar getransformeer kan word tot teologiese teorieë wat inderdaad daarin sou kon slaag om sowel op ons insig as op ons ervaring te appelleer?' (Van Huyssteen 1986: 1).

Van hieruit, as 'n voorlopige gevolgtrekking wat terselfdertyd deel van sy uitgangspunt word, kom hy by die volgende definisie van die sistematiese teologie tereg. 'Die proses waarin op 'n geloofwaardige en kritiese wyse teoretiese verantwoording oor ons christelike geloof afgelê word' (Van Huyssteen 1986: 2). Om dit te kan doen, tree hy in gesprek met die wetenskapsfilosofie as dié onderafdeling van die filosofie wat hom besig hou met ' $n$ analise en kritiese waardering van die vooronderstellings van die wetenskap. Hy kies hierdie weg omdat hy die uitdaging aanvaar om die begrip rasionaliteit, ten spyte van sy geladenheid en die gevolglike negatiewe beoordeling daarvan binne die teologiese denkwêreld, op 'n geldige wyse vir die teologie te herwin.

Hierdie keuse sou die vermoede kón laat ontstaan dat hy hom besig hou met wat reeds die 'eksterne' prolegomena genoem is en wat veral binne Rooms-Katolieke kring as 'fundamentele' teologie bekend is. Dit sou beteken dat hy nie werklik met teologie in die eng sin van die woord besig is nie, maar eerder met wat Barth (1947: 41) die 'Vorher zu sagende Dinge' genoem het. Dit sou beteken dat sy werk verstaan moet word as 'n stuk apologetiek wat die bedoeling het om die Christelike geloof - en veral die formulering wat dit binne die raamwerk van die kerklike tradisie gevind het - vir die moderne gesekulariseerde wêreld op een of ander manier rasioneel bewysbaar te maak. Dit is egter nie sy bedoeling nie. Hy verkies om van sy kennisweg te praat as " $n$ fundamenteel-teologiese problematisering van die sistematiesteologiese denkwyse self'.

Dit doen hy omdat dit sy oortuiging is dat 'elke sistematiese teoloog die een of ander tyd die fundamentele teoretiese vraag na die aard en 
struktuur van sy eie denkmodel moet vra terwyl elke vorm van fundamenteel-teologiese problematiek uiteindelik weer volledig binne die raamwerk van die sistematiese teologie kontekstueel moet word' (Van Huyssteen 1986: 2). Hy is dus, volgens sy eie insig, volledig besig met die 'interne' prolegomena en dus alreeds met sistematiese teologie van die eerste orde.

Dit alles ten dienste van sy oorkoepelende strewe, naamlik om 'n teologie te bedryf wat ' $n$ kreatiewe daad is, en nie net die onkritiese wakkerhou en herhaling van tradisie nie. Maar dan tog 'n kreatiewe daad wat bewustelik gedra word deur die tradisie waaruit die teoloog voortkom, op so 'n wyse dat die moontlikheid van 'n meervoudigheid van teologiese uitsprake aan die lig kan tree, deurdat die klem steeds val op die voorlopigheid en tentatiwiteit daarvan. Daarby is sy ideaal'n teologie wat nie tot isolasie veroordeel is nie, maar sonder enige voorbehoud en geheel en al as gespreksgenoot binne die raamwerk van die breë wetenskaplike gesprek aanvaar word.

Of en in hoeverre hy hierin slaag, sal eers duidelik word wanneer sy kennisweg saam met hom afgelê word.

\subsection{Sy kennisweg}

\subsubsection{Barth en die logies-positiwisme}

Die eerste stap op hierdie kennisweg is Van Huyssteen se poging om aan te dui hoe die logies-positiwisme en die dialektiese teologie van Karl Barth cum suis, alhoewel teenoormekaarstaande, tog bipolêr aan mekaar verbind is. Hy toon naamlik bevredigend aan dat die dialektiese teologie, in reaksie teen die eensydige eise van die logiespositiwisme, 'n standpunt handhaaf wat uiteindelik óók as 'n soort positiwisme beskou kan word. Hiermee gee hy dan ineens ook Dietrich Bonhoeffer, wat Karl Barth indertyd alreeds beskuldig het van openbaringspositiwisme, gelyk.

Die kenmerk van elke vorm van positiwisme is dat dit een of ander definitiewe gegewe as finale basis vir alle argumentasie aanvaar (Van Huyssteen 1986: 16). Die definitiewe gegewe waarop die logiespositiwisme bo alles gebou het, was die oortuiging dat kennis net waar kan wees as dit sintuiglike waarneming tot grondslag het. Van hieruit volg die sogenaamde verifieerbaarheidseis en die visie dat alle wetenskap één is, met één metode en één kriterium vir waarheid. As model vir ware wetenskaplikheid is die natuurwetenskappe, as die mees ontwikkelde wetenskap van die dag geneem en volgens die strak 
natuurwetenskaplike wêreldbeskouing wat hieruit voortgespruit het, is alle metafisiese uitsprake as kognitief sinloos verwerp. Logika en feitelikheid vorm die grondslag van die positiwistiese standaardbeeld in die wetenskap en struktureer spesifiek die rasionaliteitsmodel van die positiwistiese paradigma (Van Huyssteen 1986: 21).

Alhoewel Van Huyssteen die skerp kritiek van ander teen Barth se reaksie hierop deel, gee hy toe dat die reaksie moeilik ánders daar kon uitsien! (Van Huyssteen 1986: 23). Dit behoort immers vanaf die eerste oomblik duidelik te wees dat die teologie onmoontlik nie die positiwistiese wetenskapsbeeld sou kon aanvaar nie. Die aansprake en uitsprake van die teologie is ten ene male nie empiries verifieerbaar nie en deur die positiwistiese oordeel oor metafisiese uitsprake sy eie te maak, sou hy wetenskaplike selfmoord pleeg. Dat Barth in reaksie teen hierdie eensydigheid en gesien die felheid van die positiwistiese propaganda, sou vergly in ' $n$ posisie wat as openbaringspositiwisme gekarakteriseer kon word, was nagenoeg onvermydelik.

Van Huyssteen se volledige analise van die Barthiaanse standpunt dui bevredigend aan dat Barth nie nét in reaksie teen die logiespositiwisme is nie, maar óók teen die historiese relatiwisme en psigologiese subjektiwisme van die 19de eeu (Van Huyssteen 1986: 27). Hy slaan egter drie vlieë met één klap, wanneer hy die absolute prioriteit van God se openbaring in Jesus Christus as die fokuspunt van alle teologiese denke aandui. Teologie is vir hom net teologie in soverre as wat dit openbaringsteologie is wat sy objek in God vind - God, wat deur sy vrymagtige openbaring in werklikheid die eintlike subjek van die teologie is.

Op hierdie wyse 'red' Barth die teologie deur daarvan 'n eiesoortige wetenskap te maak. Die finale en onbevraagtekenbare basis vir alle argumentasie is volgens sý standpunt die openbaring. Die aanspraak is duidelik: Hieroor kan die teologie iets sê, maar geen ander wetenskap nie - juis omdat hier nie sprake kan wees van empiriese verifieerbaarheid nie! Daarom is Van Huyssteen heeltemal reg wanneer hy aantoon dat hierdie standpunt van Barth uiteindelik daartoe moet lei dat die teologie volkome geïsoleer word en dat dit hoogstens ' $n$ esoteriese aangeleentheid sal bly waarby net ' $n$ groep ingewydes enige belang sal hê.

Die kritiese vrae wat hy uiteindelik aan die Barthiaanse ontwerp stel, is snydend en betekenisvol. Het dit Barth geluk om sy vertrekpunt vir 'n ware teologie werklik by God en sy openbaring te vind en nie dalk in 'n subjektiewe voorstelling oor God en sy openbaring nie? (Want dit 
moet in gedagte gehou word dat Barth nooit sy eie uitgangspunt bevraagteken nie.) Het die rasionaliteitsmodel wat: Barth hanteer het, dit inderdaad vir hom moontlik gemaak om die historiese relatiwisme en die psigologiese subjektiwisme te oorwin?

Die implisiete gevolgtrekking waartoe hy kom, is: nee! Sy gevolgtrekking is dat Barth, in sy reaksie teen die eise van die positiwistiese wètenskapsbeeld, op 'n subtiel-teologiese wyse uiteindelik binne die raamwerk van presies hierdie soort denkmodel gevange gebly het (Van Huyssteen 1986: 29). Daarom word dit vir hom duidelik dat die Barthiaanse, of 'n soortgelyke antwoord, nie bevredigend is of kan wees nie. Dit word vir hom verder duidelik dat die waarheidsvraag in die teologie (en dus ook die vraag na die wetenskaplike gehalte van teologiese denke) nie staan of val by die een of ander positiwisties gestruktureerde verifikasieproses nie, maar in die eerste plek by die vraag na die wyse waarop teologiese uitsprake tot stand kom (Van Huyssteen 1986: 35).

As 'n eerste treetjie op pad na die beantwoording van hierdie vraag, neem hy sy leser op 'n ontdekkingstog deur die moderne wetenskapsfilosofie en by name deur die denke van die moderne grootmeesters Karl Popper en Thomas S Kuhn.

\subsubsection{Die kritiese rasionalisme en die paradigmateorie}

Van Huyssteen dui myns insiens bevredigend aan dat, as die teologie 'n rasionaliteitsmodel wil nastreef wat teologiese uitsprake in breëre konteks aanvaarbaar sal maak, dit by die logies-positiwistiese rasionaliteitsmodel moet verbygryp. Dít hoef die teologie egter nie op eie houtjie te probeer doen nie, aangesien daar reeds binne die wetenskapsfilosofie as sodanig ontwikkelings plaasgevind het wat opwindende alternatiewe bied.

Van Huyssteen gee 'n insiggewende en vlymskerp analise van die kritiese rasionalisme van Popper en die paradigmateorie van Kuhn. Weens gebrek aan ruimte gee ons net aandag aan daardie fasette van die analise wat direkte betekenis het vir die problematiek waarmee hy besig is.

Wat Popper betref: Hy verwerp die verifikasie-eis en die sogenaamde induksiebeginsel van die positiwisme. Wat laasgenoemde betref, stel hy byvoorbeeld dat geen aantal identiese waarnemings sonder meer hoef te lei tot die konklusie van 'n algemene wet wat geldig is vir alle soortgelyke gevalle nie. Saam met die idee van induktiewe bevestiging, verwerp hy ook 'n basis van objektiewe feite wat deur objektiewe 
waarneming verkry is. Teenoor 'n denkhouding wat hierdeur gekenmerk word en wat hy as dogmaties aandui, pleit hy vir wat hy noem 'n kritiese denkhouding. Dit word gekenmerk (aldus Popper) deur 'n vrye diskussie van teorieë met die doel om die swak plekke in hierdie teorieë op te spoor en uit te skakel.

Wat die teorieë as sodanig betref: Popper verwerp die moontlikheid van neutrale of objektiewe waarneming. Volgens hom vooronderstel elke vorm van waarneming alreeds 'n gesigspunt of teorie van waaruit die waarneming moontlik word en realiseer. Sy kritiese rasionalisme is gevolglik 'n kritiese proses van vrye en konstruktiewe rasionaliteit waarin die sterkste teorieë uiteindelik oorleef en die swakkeres uitgeskakel word. In ooreenstemming hiermee verwerp hy ook die aanspraak van die logies-positiwisme dat metafisiese uitsprake as sodanig betekenisloos is. Om egter te kan onderskei tussen metafisiese uitsprake wat as wetenskaplik en dié wat as ónwetenskaplik kan geld, soek hy na 'n beginsel van onderskeiding en vind dit in die sogenaamde valsifiseerbaarheidskriterium. Die rasionele karakter van wetenskaplike denke lê volgens hom in die ontdekking en uitskakeling van foute.

Ten laaste is dit ook nog belangrik om die aandag daarop te vestig dat Popper 'n duidelike en positiewe funksie aan metafisiese uitsprake toeken. Só positief inderdaad, dat hy stel dat metafisiese idees geïmpliseer is in alle vorms van wetenskaplike ondersoek in die sin dat hipoteses in die wetenskap dikwels deur die nie-wetenskaplike, die metafisiese, begelei word. Dit spreek vanself dat hierdie nuwe rasionaliteitsmodel vir wetenskap nuwe moontlikhede open vir daardie wetenskappe, soos die teologie, wat nie aan die eise van die logiespositiwisme kan voldoen nie.

Daar kom egter ook vanuit hierdie kring felle kritiek op die teologie en sy uitsprake, soos Van Huyssteen dit aandui wanneer hy William W Bartley aan die woord stel. Sý basiese kritiek teen die teologie is dat dié hom probeer onttrek aan kritiek en pogings tot valsifikasie, deur die toepassing van 'n soort immuniseringstaktiek. Dit val naamlik terug op 'n soort irrasionele subjektiwisme waar 'n laaste geloofsoortuiging, waaragter daar nie teruggevra kan word nie, die uitgangspunt van alle teologiese diskussie gemaak word.

Alhoewel Van Huyssteen op skerpsinnige manier aantoon dat Bartley presies dit doen waarvan hy die teologie beskuldig, maak hy tog erns met dié se kritiek. Tot so 'n mate so dat een van die basisprobleme waarop hy 'n antwoord soek, juis die vraag is of dit vir 'n teoloog 
überhaupt moontlik is om hom met sy teologiese tradisie te identifiseer en tog nog rasionele integriteit te behou (Van Huyssteen 1986: 60). Daarby kom ook nog die verdere vraag of die teoloog ' $n$ rasionalisteitsmodel kan formuleer op ' $n$ manier waarop die teoretisering wat sy eie subjektiewe inset meebring, reeds van die begin af verantwoord kan word.

Uit sy behandeling van die paradigmateorie van Thomas $\mathbf{S}$ Kuhn word dit duidelik dat Van Huyssteen nóu daarby wil aansluit, omdat hy in die rasionaliteitsmodel wat hier ontwikkel word, opwindende moontlikhede vir die sistematiese teologie sien.

Hierdie teorie kom kortliks op die volgende neer: Wetenskaplike denke is 'n sosiale, histories-bepaalde aktiwiteit wat oorheers word deur die rol wat paradigmas daarin speel. So 'n paradigma word deur Van Huyssteen omskryf as 'n eksemplaar of probleemoplossingsmodel waardeur die wetenskaplike dié deel van die werklikheid wat hom interesseer, benader (Van Huyssteen 1986: 66). Anders gesê, dit is 'n model waarkragtens ' $n$ bepaalde wetenskaplike gemeenskap, sy wetenskaplike arbeid verrig.

Stellig die belangrikste saak wat Kuhn in verband met hierdie paradigmas stel, is dat wetenskaplike denke nie akkumulatief nie, maar skokgewys ontwikkel. Dit gebeur deurdat die een paradigma plek moet maak vir 'n ander. Dit gebeur telkens by wyse van 'n rewolusie.

Die Kuhniaanse teorie sien, baie vereenvoudigd, soos volg daaruit: Aan die beginpunt van 'n wetenskap staan ' $n$ sogenaamde preparadigmatiese periode. Dit word eerstens daardeur gekenmerk dat daar nog nie onderlinge ooreenkoms is oor die model wat gevolg sal word nie en tweedens dat wetenskaplikes hulle nog besig hou met verskillende hipoteses en teorieë.

Die fase van normale wetenskap volg wannneer daar, om een of ander rede, gekies word vir 'n bepaalde teorie of model wat die beste daartoe in staat blyk te wees om die raaisels waarmee die wetenskaplikes gekonfronteer is, op te los. Hier kry ons dan ook te make met Kuhn se ideaal vir wetenskaplikheid. Die wetenskaplikheid van 'n teorie hang nie vir hom, soos vir Popper, saam met valsifiseerbaarheid nie, maar met sy vermoë om raaisels op te los. Dit is dan sy rasionaliteitsmodel vir wetenskap.

Die fase van rewolusionêre wetenskap volg wanneer dit al duideliker word dat die aanvaarde model of paradigma nie meer daartoe in staat is om bevredigende oplossings vir raaisels te bied nie. Die gevolg is dat vertroue in die paradigma begin wankel. Vanuit hierdie krisissituasie 
kan die wetenskaplike nou deur 'n kreatiewe sprong tot 'n totaal nuwe kyk op die werklikheid en sy probleme kom. Die gevolg hiervan is dan die totstandkoming van 'n nuwe paradigma waardeur die tradisionele manier van doen, sowel as die effektiwiteit daarvan, onherroeplik deurbreek word. Die onherroeplikheid daarvan is geleë in die feit dat'n nuwe paradigma nie by wyse van rasionele argumentasie tot stand kom nie, maar steeds gebore word uit wat Kuhn 'flashes of intuition' noem en deur Van Huyssteen beskryf word as 'n 'bekeringservaring'.

Die belangrikste gevolgtrekkings wat Van Huyssteen uit hierdie teorie maak, is in sy eie woorde die volgende:

- ... metafisiese idees kan nooit gesien word as bloot deel van die eksterne en toevallige voorwaardes vir die groei van wetenskaplike kennis nie, maar hierdie idees is inderdaad binneparadigmaties konstitutief vir sowel die betekenis as die geldigheid van wetenskaplike teorieë self (Van Huyssteen 1986: 72).

-...'n nuwe wetenskapstradisie wat voortvloei uit 'n wetenskaplike rewolusie (is) onversoenbaar en dikwels ook onvergelykbaar met die tradisie wat daaraan voorafgegaan het (Van Huyssteen 1986: 75).

- Die begrip waarheid is ' $n$ begrip wat slegs intra-paradigmaties gebruik kan word, en het daarom ...'n sekere lokale en definitief voorlopige karakter (Van Huyssteen 1986: 78).

- Rasioneel is dit waartoe 'n bepaalde wetenskaplike gemeenskap saam besluit het, en enige a-historiese rasionaliteitskonsep moet langs hierdie weg as illusionêr ontmasker word (Van Huyssteen 1986: 78).

- Ook die sistematiese teologie, as intellektuele aktiwiteit, is as sosiologies-historiese denkvorm altyd paradigma-bepaald (Van Huyssteen 1986: 80).

- Ook teologiese refleksie is dus oral en altyd 'n groepgebaseerde aktiwiteit (Van Huyssteen 1986: 81).

- Ook in die sistematiese teologie kan 'n paradigmatiese verskuiwing as konseptuele transformasie slegs plaasvind indien dit geintegreerd oor die hele linie van 'n teoloog se totaalbeskouing plaasvind (Van Huyssteen 1986: 82).

- Verset teen so'n nuwe (geloofwaardige) denkmodel ... kan dus plaasvind wanneer 'n teoloog of groep teoloë hierdie konseptuele transformasie nie meegemaak het nie (Van Huyssteen 1986: 84). 
- Al teologiserende binne verskillende paradigmas of denkmodelle kan twee teoloë of twee groepe teoloë verskillende probleme identifiseer en oplossings inisieer wanneer hulle vanuit skynbaar dieselfde grondoortuiging of vertrekpunt (vergelyk byvoorbeeld die gesag van die Skrif as geopenbaarde Woord van God) in dieselfde rigting ('n bybelse oplossing vir die probleem) werk (Van Huyssteen 1986: 84).

- Voordat teoloë werklik sinvol kan kommunikeer, moet 'n paradigmaverskuiwing eers plaasvind (Van Huyssteen 1986: 85).

- ... ons moet gewaarsku wees ... vir enige teoloog wat outoritêr daarop aanspraak maak dat sy teologiese tradisie die enigste ware (of bybelse) tradisie is (Van Huyssteen 1986: 86).

Die wetenskapsfilosofiese insigte van Kuhn het verreikende implikasies vir die teologie en vir álle wetenskap. Bloot net die insig dat rasionaliteit geleë is in dit waarop ' $n$ bepaalde wetenskaplike gemeenskap saam besluit het - en dat die begrip 'waarheid' net binne ' $n$ bepaalde paradigma gebruik kan word, beteken dat die één wetenskap hom nie kan uitlaat oor die wetenskaplikheid al dan nie van ' $n$ ander nie. Verder, soos 'n veelheid van wetenskaplike modelle hierdeur gelegitimeer word, word ' $n$ veelheid van teologieë nie net moontlik nie, maar onontwykbaar. Dit, op sy beurt, het radikale implikasies vir die binne-teologiese gesprek, vir tussen-kerklike kommunikasie, vir die ekumeniese verband en vir die (gesamentlike) kerklike getuienis. Van Huyssteen se simpatieke aanvaarding van hierdie insigte, het uiteindelik ook radikale konsekwensies vir sy model.

\subsubsection{Op pad na 'n eie antwoord}

Sonder om in te veel detail te verval, moet daar (oorsigtelik) aandag gegee word aan Van Huyssteen se Auseinandersetzung met Pannenberg en Sauter, dié twee teoloë wat die uitdaging van die hedendaagse wetenskapsfilosofiese gesprek aanvaar het. Dit is nie in die eerste plek belangrik as gevolg van Van Huyssteen se knap en insiggewende analise van hulle standpunte nie, maar vir die aanduidings waar hy met hulle saamstem of van hulle verskil.

Hy het hoë waardering vir die wyse waarop Pannenberg, van die kant van die teologie, die gesprek met die wetenskapsfilosofie opgeneem het en betuig veral instemming met dié se kriteria vir die kontrolering van teologiese teorieë wat Van Huyssteen (1986: 120) soos volg formuleer: 
1. teologiese uitsprake moet op aanduibare en navolgbare wyse die essensie van die bybelse boodskap uitspreek;

2. teologiese uitsprake moet voortkom vanuit 'n universeel gekonsipieerde teologie, moet die betrokkenheid van die werklikheid op God tematiseer en moet dus ten nouste korreleer met die probleemvlak van die huidige filosofiese en wetenskapsfilosofiese probleembewustheid;

3. teologiese uitsprake moet menslike ervaring op die mees sinvolle wyse integreer;

4. teologiese uitsprake moet volkome op die hoogte wees met die stand van sake in die huidige teologiese probleembewussyn.

Hy is veral in sy skik met die feit dat Pannenberg aangetoon het dat die teologie ' $n$ verpligting tot rasionaliteit het ter wille van die waarheidsbewussyn van die Christelike geloof. Hy betuig ook instemmig met Pannenberg se poging om aan te toon dat die sistematiese teologie met die werklikheid in sy totaliteit te make het.

Sy kritiek teen Pannenberg is dat hy te ver agteroorleun om die kritiek van die kritiese rasionalisme te middele te wees. Dit word duidelik uit die feit dat Pannenberg nie aan die geloofsbeslissing as commitment van die teoloog, ' $n$ rol in die ontwikkeling van teologiese teorieë wil toeken nie. Wanneer Pannenberg stel dat die herkoms van teologiese teorievorming teruggevoer kan word na die wyse waarop gelowiges die werklikheid rondom hulle ervaar ('n insig waarmee Van Huyssteen dit eens is), is dit tog duidelik dat die geloofsverbintenis van die teoloog nie daaruit weggeredeneer kan word nie - aldus, ten regte, Van Huyssteen. Hy bespeur by Pannenberg die vrees dat ' $n$ erkenning van die feit dat ' $n$ teologiese interpretasie vanuit 'n persoonlike geloofsverbintenis na vore kom, 'n prysgawe van die teologie aan onwetenskaplikheid en nie-rasionaliteit sal wees. Daarom word hierdie saak glad nie in sy denkmodel verantwoord nie en lei dit tot ' $n$ bepaalde ambivalensie in sy denke, deurdat hy dit steeds nodig vind om heen en weer te beweeg tussen die wêreld van die geloof enersyds en die wêreld van kritiese denke andersyds.

By Sauter figureer die enge verbondenheid tussen geloof en teologie veel sterker. Soos Pannenberg wil hy nie 'n standpuntteologie hê nie en kies ten gunste van 'n argumentatiewe teologie waarin daar nie vanuit vooropgestelde en ongekontroleerde sekerhede vertrek word nie. In sy sogenaamde analities-teoretiese denkmodel geld geloof en openbaring nie sonder meer en kritiekloos as vooronderstelling van teologiese 
uitsprake nie, maar word dit tot objek van kritiese vraagstelling. Dit beteken dat wat in geloofservarings beleef en geformuleer word, vir hom binne teologiese konteks geregverdig moet word. Gesien sy kritiek teen Pannenberg, is dit begryplik dat Van Huyssteen hom hiermee sou identifiseer.

Sy kritiek teen Sauter is dat hy nie voldoende besin oor die wyse waarop die persoonlike geloofsverbintenis van die teoloog reeds verteoretiseer en verkonseptualiseer is nie. Volgens Van Huyssteen is geloofsuitsprake, wat deur Sauter as assertoriese uitsprake aangedui word en van teologiese uitsprake onderskei word, reeds vanweë hulle verbondenheid met en oorsprong in geloofservarings, verteoretiseer deur die agtergronds- en omgewingsfaktore wat die sogenaamde konteks van ontdekking van die gelowige teoloog uitmaak. Hieruit kom sy grootste en belangrikste kritiese beswaar teen Sauter, naamlik dat hy, téén die bedoeling van sy eie ontwerp in, nie aan die verwyt sal kan ontsnap dat hy geloofsuitsprake onkrities en probleemloos wil aflei uit die geloofsverbintenis van die teoloog nie. Daarby kom dan ook nog die feit dat Sauter, wat die kontrole van teologiese uitsprake betref, kerk en belydenis op 'n (vir Van Huyssteen) onbehoorlike wyse inbou. Sauter stel naamlik dat die teologie, wat die uitdink van idees betref, aan die kerk en sy tradisie van nadenke gebonde bly. Van Huyssteen (1986: 147) sien hierin die gevaar van wat hy noem: "'n ekstreme kerklike konvensionalisme; 'n tipe van konvensionalisme waar die kerktaal van 'n bepaalde plek of tyd tot grondslag van die geldigheid van sistematiesteologiese uitsprake word.' Dit sou die deur open vir die saak wat hy bo alles probeer oorwin, naamlik positiwistiese dogmatisme en tradisionalisme. Die vraag is net of daar nie hier by Van Huyssteen iets te bemerk is van wat as belydenisweersin of onkonfessionaliteit beskou sou kon word nie. Meer hieroor later.

\subsubsection{Die eie antwoord}

Hierbo is reeds verwys na Van Huyssteen se oortuiging dat die vraag na die wetenskaplike gehalte van die teologiese proses van nadenke nie staan of val met een of ander positiwisties-gestruktureerde verifikasieproses nie, maar in die eerste plek met die vraag na die wyse waarop teologiese uitsprake tot stand kom. Die rasionaliteitsmodel wat hy aanbied, steun in die eerste plek en oorwegend op 'n poging om juis aan te toon hoe dit gebeur.

Sy uitgangspunt is dat die vraag na die aard en herkoms van 
teologiese uitsprake, die vraag na die struktuur van geloofsuitsprake is (Van Huyssteen 1986: 158).

In die eerste plek dui hy geloofstaal dan aan as relasionele taal, oftewel taal wat 'n relasionele struktuur vertoon. Dit is daaraan te danke dat die gelowige (ook die gelowige teoloog), vanuit die grondverbintenis van sy geloofsoortuigings op betrokke wyse uitsprake maak wat verwys na ' $n$ werklikheid buite homself. Hy formuleer soos volg:

... die wyse waarop die teoloog as christengelowige sy of haar geloof ervaar en die aard van die daaruitvoortvloeiende geloofstaal, is uiteindelik medebepalend vir sowel die teologiese as wetenskapsfilosofiese status van teologiese uitsprake (1986: 154).

Sy aansluiting by Sauter se standpunt dat enige teorie van die teologie in die eerste plek 'n vorm van taalanalise is, kom hier baie duidelik na vore. Hiermee saam gaan twee grondoortuigings wat soos volg geformuleer word:

1. Geen geloofservaring kan as pre-linguisties of voor-teoreties gesien word nie;

2. alle relasionele geloofstaal verwys direk of indirek na God. As sodanig is geloofstaal nooit bloot eksklusief nie, maar bevat dit 'n kognitiewe kern wat in die ontsluitende of verwysende strukture daarvan na vore kom (Van Huyssteen 1986: 154).

Wat die aard van geloofstaal betref, moet gestel word dat Van Huyssteen dit as metafories karakteriseer. Hy definieer ' $n$ metafoor as ' $n$ wyse van taalgebruik waarin die taal self gerek word om nuwe insig te bring; om iets te verstaan wat vroeër nie verstaan kon word nie. Daarmee wil hy aandui dat die metafoor nie bloot ' $n$ wyse van kommunikeer is nie, maar inderdaad 'n wyse van ken. Soos hy dit verstaan, is die bevrydende van metaforiese taalgebruik daarin geleë dat daardeur insig in aspekte van ons werklikheid wat nie in letterlike taalgebruik formuleerbaar is nie, bemiddel of ontsluit word.

Die geloofservaring kan nie anders as in metaforiese taal vasgevang word nie. God as God, as die Onsigbare en Transendente, kan nie andersins 'vasgevat' word nie, want aangesien Hy buite die kategorieë van ruimte en tyd staan en nie vir die sintuie toeganklik is nie, onttrek Hy Homself aan die formuleringsmoontlikhede van ons alledaagse taal. Die verbintenis wat die gelowige met Hom ervaar - hierdie engagement wat die dieptedimensie van sy menswees konstrueer en wat roep om 'gesê' te word - maak die metafoor noodwendig en onontbeerlik. 
Dit gaan egter verder. Die metafoor herbeskryf die werklikheid omdat dit aandag vra vir die dieper dimensie daarvan. Daarom 'transformeer dit uiteindelik ons taal sowel as ons perspektief op die werklikheid wat dit herbeskryf' (Van Huyssteen 1986: 163) en gee dit aanleiding tot die opkoms van 'n meer relasionele waarheidsbegrip. Van Huyssteen dui ook bevredigend aan dat, soos die teologie, alle wetenskappe wat met onsigbare entiteite soos atome, waardes en intelligensie werk, onvermydelik op metaforiese taalgebruik aangewese is. Daar is dus selfs sprake van so iets as 'n metaforiese denkbeweging wat ' $n$ kenmerk van menslike kennis as sodanig is. Die implikasie hiervan is 'dat alle menslike kennis - dus ook teologiese kennis tentatief, dinamies, histories en relasioneel (moet) wees' (Van Huyssteen 1986: 163).

Vanuit die grondoortuiging dat taal nie net die werklikheid verteenwoordig of weerkaats nie, maar dit ook konstitueer, kom vervolgens die stelling dat daar vanuit die metaforiese spreekwyse modelle ontstaan vir die daarstelling van teorieë of netwerke van teorieë. Van Huyssteen wys daarop dat die metafoor 'Vader' 'n dominante model in die Christelike spreekwyse oor God geword het. So 'n model funksioneer dan as 'n uitgebreide en gesistematiseerde metafoor in terme waarvan verklaar word. So 'n model, synde alreeds 'n vermenging van metafoor en teoretiese konsep, speel volgens Van Huyssteen binne die konteks van die Christelike geloofstradisie 'n belangrike rol omdat dit tussen die metaforiese aard van geloofstaal en die teoretiese aard van teologiese taal geleë is, en as dominante metafore die prioriteit van daardie tradisie beklemtoon.

Naas die ooglopende belangrikheid hiervan, is daar ook ' $n$ gevaar aan verbonde. So 'n model kan naamlik só belangrik word, dat dit die status van ikoon kan verkry. Dit kan dan lei tot verideologisering. Wat in ieder geval gebeur, is dat bepaalde modelle so allesomvattend word dat hulle as onveranderlike grondmetafore begin funksioneer. Die grondmetafoor van die Christelike geloof dui Van Huyssteen (1986: 167) aan as 'verlossing in Jesus Christus'. In dié verband maak hy die volgende, baie belangrike stelling:

Wat van groot belang is, is dat in die uiteindelike daarstelling van teologiese konsepte en die bundeling van teologiese uitsprake tot teologiese teorieë, hierdie reflekterende teoretiese taal getrou moet bly aan sy metaforiese oorsprong en die binding daarvan aan 'n bepaalde grondmetafoor (Van Huyssteen 1986: 167). 
Daarby moet dit ook op'n geldige wyse in die werklikheidservaring en wetenskaplike probleembewussyn van ons tyd weerklank vind. Vir, soos hy dit noem die 'riskante tipe van evaluering' wat hierdeur vereis word, stel hy dan drie kriteria vir 'n geldige sistematies-teologiese rasionaliteitsmodel.

- Die werklikheidsbetrokkenheid van teologiese uitsprake.

- Die kritiese en probleem-oplossende vermoë daarvan.

- Die ontwerpende en progressiewe aard daarvan.

Hiermee het ons dan saam met hom aangekom by die hart van sy kritiese realisme, wat Van Huyssteen (1986: 168) soos volg omskryf:

... (dit) is realisties omdat met hierdie begrip in die proses van teologiese teorievorming die kognitiwiteit en verwysende aard van analogiese taalgebruik as vorm van indirekte taalgebruik ontsluit kan word. Dit is egter ook krities omdat die rol van die metaforiese spreekwyse ons in die teologie wil leer dat modelle nie verabsoluteer of verideologiseer kan word nie, maar tot in die proses van teoretisering hul openheid en voorlopigheid moet behou.

Belangrike gevolgtrekkings waartoe hy op hierdie stadium reeds kom, is onder andere die volgende:

- Teologie is 'n poging om dit wat ons deur ons geloofsverbintenis as die openbaring van God leer ken en leer ervaar het, so outentiek en geloofwaardig as moontlik na te dink (Van Huyssteen 1986: 170).

- Sistematies-teologies gesproke is dit daarom onvermydelik en eintlik vanselfsprekend dat daar vandag verskillende en selfs uiteenlopende konseptuele konstruksies in die vorm van ' $n$ pluraliteit van teologiese denkmodelle moet bestaan (Van Huyssteen 1986: 170).

- Die vrae na teorievorming in die teologie en na geloofwaardige kriteria vir 'n sistematies-teologiese denkmodel, is vraagstellinge wat op bo-konfessionele vlak beredeneer moet word.

- Laasgenoemde lei egter nie noodwendig tot ontkonfessionalisering van die teologie nie.

- Wanneer 'n teologie wat sy eie aard as een van kritiese geloofsverantwoording verstaan, bewus geword het van sy denkprosesse as 'n vorm van kreatiewe konseptuele konstruk- 
sie en verder ook nog kan aantoon dat sy teologiese ontwerp op sowel insig as ervaring appelleer omdat hierdie ontwerp werklikheidsbetrokke is, wanneer so 'n teologie verder krities probleme kan identifiseer en probeer oplos en op kreatiewe wyse vooruitgang vertoon, dan het so 'n teologie myns insiens daarin geslaag om op omvattende wyse 'n geldige rasionaliteitsmodel vir 'n geloofwaardige sistematiese teologie daar te stel (Van Huyssteen 1986: 173).

Vervolgens moet daar aandag gegee word aan die wyse waarop hy inhoud gee aan sy drie kriteria vir 'n geldige sistematies-teologiese rasionaliteitsmodel.

\subsubsection{Werklikheidsbetrokkenheid van teologiese uitsprake}

Wat hy hiermee bedoel, kan soos volg saamgevat word. 'Werklikheid' verwys in die eerste plek na die werklikheid van God wat direk of indirek deur alle teologiese uitsprake veronderstel word. In hierdie sin praat hy van werklikheidsbetrokkenheid as kognitiwiteit, waarby ook die rol van die subjektiwiteit van die teoloog geimpliseer is - hy wat, met die oog op hierdie werklikheid, relasionele uitsprake maak. Werklikheidsbetrokkenheid as kognitiwiteit het daarmee te make dat teologiese ontwerpe 'vooruitgrypend en voorlopig iets ontsluit van die werklikheid waarheen ons metaforiese, relasionele taal uitreik . . en in die feit dat die teologie met die verloop van tyd meer van God kan weet deur meer geldig oor Hom te praat' (Van Huyssteen 1986: 176).

Werklikheidsbetrokkenheid as kontekstualiteit weer kom daarop neer dat die teologiese ontwerp hom nie moet probeer losmaak van die kontekste waaraan hy onlosmaaklik verbonde is, waaruit hy sy probleme haal en waaraan hy sin wil gee deur geldige antwoorde op werklike probleme te gee nie.

Hy onderskei drie sodanige kontekste. In die eerste plek godsdiensbelewing as sodanig. Van Huyssteen hou vol dat dit in die sistematiese teologie nie net om eksklusief kerklik-konfessionele problematiek gaan nie. Dit gaan ook nie net daarom om binne 'n bepaalde gemeenskap hulp met die oplossing van godsdienstige probleme te verleen nie. 'Mense worstel ... ook buite bestaande kerkgenootskappe met godsdiensbelewing en daarom funksioneer die teoloog kontekstueel wanneer hy ook buite bestaande kerke geldige probleme ontdek en probeer oplos' (Van Huyssteen 1986: 180).

In die tweede plek kom die kerk as konteks na vore. Die teoloog wat in kritiese verantwoording kontekstueel en werklikheidsbetrokke wil 
spreek, sal daarom sy eie taak altyd minstens sien as 'n poging tot geloofwaardige interpretasie van die tradisie van die kerk (Van Huyssteen 1986: 181). Van Huyssteen stel egter die duidelike voorwaarde dat die teoloog binne hierdie konteks op sy hoede moet wees om nie die rol van groepsideoloog te vervul nie. Hy moet die konteks van die kerk dien, maar hy moet sy selfstandige rol as wetenskaplike behou. Daarom het die teoloog die kritiese taak om die verideologisering van modelle te probeer voorkom.

Van Huyssteen onderskei ook die teologiese refleksie as konteks. Dit doen hy omdat, soos hy dit stel, die teoloog altyd (ook) teoretikus is (moet wees) wat akademies-wetenskaplik besig moet wees en as sodanig deel van die breëre wetenskaplike gemeenskap is. Dit het uiteindelik die implikasie dat die teoloog - ook vanweë die implikasies van die waarheidsaanspraak van dit wat hy glo - 'n verpligting tot intersubjektiewe en navolgbare duidelikheid het.

\subsubsection{Die kritiese en probleemoplossende vermoë van teologiese uitsprake}

Hier leun hy swaar aan teen Larry Landau se ontwerp vir wetenskaplike probleemoplossing. À lá Landau maak hy 'n onderskeid tussen empiriese en konseptuele probleme. As empiriese probleem sou enigiets kon geld wat ons binne die Christelike geloofsparadigma as vreemd tref en dus om verklaring vra. As voorbeelde verwys hy na sake soos byvoorbeeld die sin van lyding en dood. ' $n$ Konseptuele probleem daarenteen, word veroorsaak 'deur die intellektuele interaksie wat plaasvind tussen verdedigers van uiteenlopende (selfs botsende) teorieë wat in 'n gelyke mate tog ook weer skynbaar deur dieselfde data gesteun word' (Van Huyssteen 1986: 190). Sy standpunt is dat dit ook in die teologie waar is dat dit vir ' $n$ teorie tel as dit empiriese probleme voorlopig oplos, maar téén 'n teorie as dit konseptuele prableme veroorsaak.

Sy riglyne vir 'n probleemoplossingsmodel in die sistematiese teologie is eerstens die Bybel en daarnaas die tradisie van die Christelike teologie asook die kontemporêre wetenskaplike denke.

Vir sover dit die Bybel betref, toon hy bevredigend aan dat ' $n$ teoloog die Bybel net via sy Skrifbeskouing kan benader en dat hy by voorbaat duidelikheid daaromtrent moet hê dat so 'n Skrifbeskouing 'n denkmodel is en dus kwesbaar en korrigeerbaar. Die verabsolutering van ' $n$ Skrifbeskouing is ' $n$ prysgawe van die teologiese denke aan positiwistiese verideologisering. Hy sonder die fundamentele biblisisme uit as voorbeeld hiervan en pleit, in ooreenstemming met sy oortuiging, vir 'n 
metode van Skrifberoep eerder as een van Skrifbewys (Van Huyssteen 1986: 196).

Vir sover dit die teologiese tradisie betref, maak hy 'n paar belangrike stellings:

- Refleksie oor die tradisie is 'n oproep tot voortdurende en deurlopende interpretasie.

- Dogmas en belydenisskrifte is ook maar modelle en teorieë en is dus konstruksies wat in 'n kreatiewe proses van histories-teologiese teorievorming en binne bepaalde sosiokulturele kaders en met die oog op heel spesifieke empiriese of konseptuele probleme daargestel is.

- Dogmas en belydenisskrifte is dus nie tydlose waarhede en onfeilbare kriteria vir verdere teologiese besinning nie, maar moet voortdurend in 'n tipe van 'restourasie hermeneutiek' as riglyne vir die huidige teologiese refleksie herwin word (Van Huyssteen 1986: 197).

Die implikasie hiervan is dat geen belydenis of dogma as finale of absolute interpretasie, as volledige perspektief op die wil van God, gesien word nie.

Wat die kontemporêre wetenskaplike denke betref, is sy ontwerp 'n sprekende voorbeeld van wat hy bedoel. Die verpligting tot wetenskaplike geloofwaardigheid waarmee die teoloog gekonfronteer word, maak dit noodsaaklik dat hy sal deelneem aan die breëre wetenskaplike gesprek en dat hy binne die konteks van kontemporêre wetenskaplike denke, spesifieke wetenskapsfilosofiese riglyne moet vind ter wille van die epistemologiese en metodologiese geloofwaardigheid van sy argumente en uitsprake (Van Huyssteen 1986: 204). Die teoloog moet daarop bedag wees dat sy voorteoretiese geloofsverbintenis aan God en sy openbaring nie hanteer word as rasionale verskoning vir die feit dat hy teologiese denkmodelle op 'n irrasionele wyse vanuit ondeurdagte premises ontvou nie.

\subsubsection{Die ontwerpende en progressiewe aard van teologiese uitsprake}

Van Huyssteen oordeel dat die rasionaliteit van 'n teologiese uitspraak nie meer afhanklik is van die vermeende vermoë daarvan om sonder meer, op fundamentalistiese wyse, die waarheid te praat nie. Dit is afhanklik van die vraag of dit vordering of vooruitgang vertoon deur probleme te verminder of op te los. 'Eenvoudig gestel, teologiese vooruitgang beteken om die Bybelboodskap telkens binne elke nuwe 
konteks of probleembewussyn, opnuut maar ook beter te verstaan (Van Huyssteen 1986: 210).

\section{BEOORDELING}

Dit behoort duidelik te wees dat Van Huyssteen se ontwerp suksesvol is, in soverre as wat hy bereik wat hy homself ten doel gestel het. Die grootste winspunt van die ontwerp is ongetwyfeld sy aanduiding van die feit dat die teoloog nie nodig het om hom aan 'n positiwisme prys te gee om sodoende die wetenskaplikheid van dit waarmee hy besig is, te probeer beredder nie. Sy diensbaarmaking van die wetenskapsfilosofiese insigte van Popper en Kuhn verdien in hierdie verband veral vermelding. Deur aan te haak by die rasionaliteitsmodelle wat deur hulle ontwerp is en weg te beweeg van die eenheidsvisie op die wetenskap wat die nalatenskap van die logies-positiwisme is, skep hy inderdaad die ruimte daarvoor dat die teologie nie nodig het om, soos hy self dit by voorkeur stel, 'n ghettobestaan in wetenskaplike isolasie te voer nie. Na die diensbaarmaking van hierdie byderwetse wetenskapsfilosofiese insigte, is dit duidelik dat die wetenskaplike geloofwaardigheid van die teologie nie meer 'n probleem hoef te wees nie. Die oeroue vraag, of die teologie 'n wetenskap is al dan nie, word hier dus nie beantwoord deur te probeer bewys hoe en in hoeverre die teologie beantwoord aan bepaalde wetenskaplike eise nie, maar deur aan te dui dat 'wetenskap' daar anders uitsien as wat die populêre opvatting sou vermoed. Die oomblik as die verifikasie-eis en die induksiebeginsel nie meer geld as die enigste normatiewe toets vir wetenskaplikheid nie en dit toegegee word dat wetenskapsbeoefening nie vooronderstellingsloos en buiteparadigmaties kan plaasvind nie, is die wetenskaplikheid van die teologie nie meer in beginsel 'n probleem nie.

Dit is verder duidelik dat veral die invalshoek van sy ontwerp, die vraag naamlik na die 'hoe' van die totstandkoming van teologiese uitsprake, enige vorm van verideologisering binne die struktuur van die teologie behoort te verhinder. Met so 'n model is verstarring bykans onmoontlik. Die gebruikmaking van die relasionele waarheidsbegrip behoort daarvoor sorg te dra dat dogmatisme kwalik voorkom en daar sal sprake wees van broodnodige soepelheid en beweegbaarheid. Byderwetse probleme sal eietydse antwoorde kry terwyl die belydenisskrifte en dogmata voortdurend herinterpreteer sal word sodat hulle hulle wesenlike rol sal kan bly speel. 
Die ontwerp sal verder daartoe lei dat die teoloog hom verantwoord ten opsigte van sy vooronderstellings en metode. Dit sal beskeidenheid aanmoedig en die teoloog beskerm teen die 'sonde' van absoluutheidsaansprake ten opsigte van sy eie visies. Laasgenoemde sal moontlik wees omdat elke teoloog bewus sal wees van die voorlopigheid van sy uitsprake (asook van die modelle wat sy uitsprake ondersteun). Dit impliseer dat elke teoloog bewus sal word van die moontlikheid (en werklikheid) van verskillende, naasmekaarstaande teorieë met ewe veel aanspraak op waarheid en geldigheid. Dit sal onmiddellik weer daartoe aanleiding gee dat die pluriformiteit (selfs pluraliteit) van die kerk 'n behoorlike teologiese onderbou verkry. Veral die aanvaarding van die Kuhniaanse paradigmateorie het radikale implikasies in hierdie verband - veral betreffende die verhouding tussen die kerke. Die konsekwensie hiervan is dat daar, gegewe bepaalde omstandighede, nie 'n gespreksmoontlikheid tussen bepaalde kerke bestaan nie - selfs al staan hulle op dieselfde belydenisgrondslag! Dit het veral implikasies vir die gesprek tussen die drie Afrikaanse kerke.

Teologiese beskeidenheid, eerlikheid, openheid en wetenskaplike integriteit - wat alles deel van die gevolge van die hantering van hierdie model kan wees, tesame met die moontlikheid dat steeds verstaanbaarder antwoorde op die groot eksistensiële vraagstellings gegee sal kan word en God steeds duideliker 'gesê' sal (kan) word, sal vir die teologie, binne die akademiese raamwerk van die universiteit, volledige aanvaarding verseker.

Die wesenlike vraag is of en in hoeverre hierdie model die diensbaarheid van die teologie aan die kerklike verkondiging ten dienste kan (sal) wees. Die belangrike vraag ten opsigte van die teologie is immers nie dié betreffende sy posisie aan die universiteit nie (nie dat dit 'n onbelangrike vraag is nie!), maar dié betreffende sy funksie binne die raamwerk van die kerk. Die teologie word wel (ook) aan 'n universiteit beoefen, maar nie ter wille van die universiteit nie. Ook nie ter wille van die wetenskaplike broederskap nie; ook nie ter wille van die gemeenskap in die brede nie. Die teologie is 'n kerklike besigheid histories en prakties. Dit word óók bedryf in die studeerkamer van elke kerklike verkondiger. Dit is nie die esoteriese breingimnastiek van 'n elite groepie beroepsteoloë nie. Dit is 'n kerklike bedryf, ter wille van die kerk en sy verkondigingstaak.

Losgemaak van hierdie verantwoordelikheid, kan dit moeilik anders as dat die teologie sal verword tot ' $n$ intellektuele spel wat op akademiese speelvelde sonder toeskouers in die pawiljoene gespeel word. Dit 
bly 'n onveranderlike eis dat die resultate van die teologie in die kerklike verkondiging, en by name in die prediking, neerslag sal vind. Betekenisvolle teologie is teologie wat die evangeliese waarheid só vertaal dat dit van die kansels af en in die pastorale gesprek eksistensiële vrae by die gemeentelede kan wakker maak èn kan beantwoord.

By nadere beskouing van Van Huyssteen se ontwerp, ontstaan die vermoede dat die begeerte om die teologie wetenskaplik aanvaarbaar te kry, by hom te veel op die voorgrond staan. Dat dit ' $n$ belangrike aangeleentheid is en dat hy kosbare insigte in die verband na vore bring, is reeds toegegee. 'n Oorbeklemtoning hiervan lei egter tot 'n onderbeklemtoning (nie ignorering nie!) van die kerklik-konfessionele binding van die teologie.

Van hierdie gevaar is Van Huyssteen se ontwerp nie vry te spreek nie. In alle billikheid moet gestel word dat hy terdeë daarvan bewus is en ook pogings aanwend om dit te minimaliseer. So stel hy byvoorbeeld meer as een keer dat sy ontwerp nie noodwendig tot ontkonfessionalisering van die teologie lei nie (bv Van Huyssteen 1986: 173). Maar die gevaar is wesenlik dáár, veral te wyte aan sy uitgesproke weersin in die bedenklike gebruik by teoloë om hulle agter ' $n$ belydenis te verskans, sonder om aan hulleself ooit rekenskap te gee van die irrasionele aard van sodanige handelswyse. Daarom wil hy, op voetspore van Pannenberg, op 'bowekonfessionele' wyse teologie bedryf wat beteken dat hy, los van konfessie en belydenis, die waarheidsvraag aan die teologie wil stel.

Vir sover as wat hy primêr besig is met sogenaamde metateologiese problematiek, kan hy selfs wat dit betref, gelyk gegee word. Heeltemal tereg merk hy op dat selfs die sistematiese teoloog wat kies vir 'n konfessionele teologie waarin die Christelike kerk as verwysingsraamwerk moet funksioneer, sal moet besef dat bo en behalwe die engere of breëre konfessionele problematiek, die vraag na die waarheidsgehalte van die teologiese uitsprake altyd latent is en homself onverwags op ' $n$ breër fundamenteel-teologiese vlak kan laat geld as 'n konkrete teologiese probleem (Van Huyssteen 1986: 182).

Toegegee, maar juis die sogenaamde 'enger of breër konfessionele problematiek' kan nie op hierdie metateologiese vlak benader word nie. En dit is uiteindelik die wesenlike problematiek. Hierin lê die waarheid van die insig wat Tillich na vore gebring het - die teoloog staan nie los van sy objek nie, nie op 'n afstand daarvan nie, maar 'involved in it' (1968: 26). Die houding van die teoloog is eksistensieel - een van 'commitment' en geloof. In hierdie eksistensiële betrokkenheid by die 
'objek' van sy wetenskaplike arbeid, word die teoloog gekonfronteer met die werklike probleme - die grondvlakprobleme waarmee die predikantteoloog van dag tot dag te make het. So 'n teoloog is deel van 'n duidelik omlynde teologiese tradisie wat bepalend is vir die konteks waarbinne hy met die eksistensiële vraagstelling, waarop hy ' $n$ antwoord moet soek, gekonfronteer word.

Enige teologiese ontwerp wat nie op radikale wyse hiermee rekening hou nie, is 'n hersenskim. Dit maak nie saak hoe verhewe sy motiewe is nie - of dit ter wille van die verdediging van die wetenskaplikheid van die teologie is of ter wille van ekumenisiteit, of ter wille van interdenominasionale universitêre fakulteite ò interkonfessionele skakeling en samewerking (almal motiewe wat implisiet of eksplisiet by Van Huyssteen aanwesig is) - dit werk nie. Bowekonfessionaliteit word so maklik onkonfessionaliteit waarmee die sinvolheid van die teologie as wetenskap ernstig in die gedrang kom.

Laat dit egter ten slotte weer 'n keer en ten owervloede beklemtoon word: dit is 'n gevaar in Van Huyssteen se ontwerp en niks meer nie. Hy sou dit waarskynlik volledig eens wees met bostaande argument en sou (waarskynlik ook ten regte) betoog dat hy nie skuldig is aan onkonfessionaliteit nie. Hy sou egter terselfdertyd moes toegee dat ' $n$ onverantwoordelike en onkritiese aanwending van sy ontwerp hierdie ongelukkige gevolg sou kon hê. Sou hy daarenteen oordeel dat hy nie reg verstaan word nie, moet hy sy ietwat duistere formulering en somtyds ambivalente spreekwyse daarvoor blameer.

Ander kommentators op sy werk sou waarskynlik allerlei ander gevare en tekortkomings uitwys. Dit is byvoorbeeld so dat die gevaar van relatiwisme nie uit die ontwerp weggeredeneer kan word nie. Maar, nadat al die gevare uitgewys is, sal toegegee moet word dat hierdie ' $n$ hoogstaande bydrae tot die teologiese debat is wat veel behoort te doen om die integriteit van die teologiese wetenskap en die geloofwaardigheid van kerklike spreke te dien.

\section{Literatuurverwysings}

BARTH, K 1947. Kirchliche Dogmatik, 1/1. Zollikon-Zürich: Evangelischer Verlag. BERKHOF, H 1973. Christelijk geloof. Nijkerk: Callenbach.

KÜNG, H 1978. Existiert Gott? München: Piper Verlag.

OTT, H 1972. Die Antwort des Glaubens. Stuttgart-Berlin: Kreuz Verlag.

TILLICH, P 1968. Systematic Theology. Digswell Place: James Nisbet and Co.

VAN HUYSSTEEN, W 1986. Teologie as kritiese geloofsverantwoording: Teorievorming in die sistematiese teologie. Pretoria: RGN. (RGN-studies in navorsingsmetodologie 2.) 